\title{
GDZIE INNOWACJA SPOTYKA SIĘ Z MARKETINGIEM. ASPEKTY TEORETYCZNE
}

DOI: 10.33141/po.2020.08.02

\section{Andrzej H. Jasiński}

\section{Wprowadzenie}

ak kiedyś trafnie zauważył guru zarządzania, P. Drucker (1973): „przedsiębiorstwo ma dwie - i tylko dwie - podstawowe funkcje: marketing i innowacje”. Marketing i innowacje produkują rezultaty; cała reszta to są koszty. Jest to oczywiste uproszczenie, bowiem i marketing, i działalność innowacyjna są bardzo kosztowne. Ale prawdą jest, że bez wprowadzania innowacji i uprawiania marketingu przedsiębiorstwo nie zapewni sobie przetrwania na rynku. Jak pisze z kolei wybitny specjalista od marketingu P. Doyle (1998, s. 1), badania dowodzą, że „osiągnięcia innowacyjne są istotnie skorelowane $\mathrm{z}$ silnym zogniskowaniem rynkowym i skutecznym działaniem wydziału marketingu”. Innymi słowy, musi istnieć ścisła współpraca między pionem innowacji/technologii a pionem marketingowym firmy. Stąd przedmiotem ba-
Przegląd Organizacji, Nr 8(967), 2020, s. 12-19

www.przegladorganizacji.pl

๑ Towarzystwo Naukowe Organizacji i Kierownictwa (TNOiK)

dań w tym artykule są powiązania pomiędzy obu sferami działalności przedsiębiorstwa ${ }^{1}$.

Przyjęto więc, że - zdefiniowana jak niżej - działalność innowacyjna współczesnego przedsiębiorstwa zazębia się z jego działalnością marketingową. Skoro tak, to hipoteza badawcza zakłada, że istnieją "punkty styczności” między obu sferami przedsiębiorstwa. Stąd celem niniejszego artykułu jest próba odpowiedzi na pytanie: Gdzie następuje to zazębianie się? Chodzi zatem o identyfikację owych „punktów styczności”. Oprócz tego podjęto próbę odpowiedzi na następujące pytania badawcze:

1. Jaką rolę odgrywa marketing w stosunku do innowacji technicznych?

2. Czy marketing jest inny w przypadku innowacji radykalnych oraz innowacji przyrostowych? 
3. Jak orientacja marketingowa przedsiębiorstwa oddziaływa na jego działalność innowacyjną?

Zastosowaną metodą badawczą jest krytyczny przegląd literatury.

Przyjęto następujące założenia do studiów literaturowych:

- z uwagi na to, że interesuje nas tutaj perspektywa menedżera innowacji w przedsiębiorstwie, $\mathrm{z}$ jego punktu widzenia prowadzono „przeszukiwanie” literatury,

- poszukiwano publikacji dotyczących powiązań między działalnością innowacyjną a działalnością marketingową, w skrócie: między innowacjami a marketingiem,

- głównym obszarem prowadzonych poszukiwań była ekonomika i zarządzanie innowacjami,

- uzupełniająco szukano w literaturze marketingowej rozważań na temat wspomnianych powiązań,

- ze względu na niezwykle ubogą literaturę krajową na temat owych powiązań studia dotyczyły przede wszystkim literatury zagranicznej, w zdecydowanej większości niedostępnej w Polsce.

Niniejsza praca ma zatem charakter interdyscyplinarny. W artykule dominują aspekty teoretyczne; badania empirycznego w tym obszarze autor jeszcze nie przeprowadził.

Zajęto się tutaj innowacjami technicznymi, które - jak wiadomo - występują w dwóch odmianach: innowacje produktowe (nowe produkty) oraz innowacje procesowe (nowe technologie produkcyjne). Innowacja techniczna/ technologiczna, według Oslo Manual (2005), ma miejsce wtedy, gdy nowy lub istotnie ulepszony produkt zostaje wprowadzony na rynek albo nowy lub istotnie ulepszony proces zostaje zastosowany w produkcji. W tym artykule interesują nas głównie innowacje produktowe. Notabene, nie każdy nowy produkt zasługuje na miano innowacji. W teorii przyjęto, że innowacja jest to nowość przynajmniej na skalę danego kraju (rynku krajowego) (Freeman, 1985). Dalej oba te pojęcia, tj. innowacja produktowa i nowy produkt, są używane zamiennie.

Innowacja jest rezultatem procesu/projektu innowacyjnego, który zaczyna się od gromadzenia pomysłów na innowację, a kończy jej komercjalizacją na rynku. Natomiast procesy innowacyjne składają się na działalność innowacyjną przedsiębiorstwa, chociaż niejednokrotnie wykraczają poza nie. Zgodnie z Podręcznikiem Oslo (OECD, 2008), działalność innowacyjna to szereg działań o charakterze naukowym (badawczym), technicznym, organizacyjnym, finansowym i handlowym (komercyjnym), których celem jest opracowanie i wdrożenie nowych lub istotnie ulepszonych produktów i procesów. Dodać należy jeszcze, że innowacyjność można określić jako zdolność i zarazem skłonność organizacji do stałego poszukiwania, absorpcji, wdrażania i upowszechniania innowacji (Matusiak, 2010).

Z kolei marketing można rozumieć trojako, tzn. jako dziedzinę nauki, zestaw praktycznych działań oraz funkcję (jednostkę organizacyjną) przedsiębiorstwa lub instytucji. Tutaj mamy na myśli marketing jako zbiór działań marketingowych firmy. Według Ph. Kotlera (1999, s. 6): „marketing jest procesem społecznym i zarządczym, dzięki któremu konkretne osoby i ich grupy otrzymują to, czego potrzebują i pragną osiągnąć, poprzez tworzenie oferowanie i wymianę posiadających wartość produktów".

Po przeglądzie literatury rozważania rozpoczęto od innowacji produktowej jako elementu marketingu-mix. Kolejne analizowane kwestie to: marketing na potrzeby innowacji, konsekwencje różnic między innowacjami radykalnymi a przyrostowymi, orientacja marketingowa a proces innowacyjny oraz wnioski końcowe.

\section{Przegląd literatury}

$\mathbf{L}$ iteratura światowa, w której pisze się o marketingu w kontekście innowacji i powiązaniach między nimi, nie jest zbyt obszerna. Podstawowe pozycje z ostatnich dwóch dekad, w których podjęto tę problematykę, to książki takich autorów, jak: W. Evers i in. (2014), D. Ford i M. Saren (2001), N. Kumar (2004), M.P. Miles i in. (2010), P. Millier (1999), J. Mohr (2001), J. Mohr i in. (2010), B. Sandberg (2008), a ponadto cztery rozdziały w pracy zbiorowej pod redakcją K. Tollin i A. Caru (2008); mowa tu w szczególności o autorach: C.M. Christensen (2008), R. Jones i K. Tollin (2008), E. Prandelli i G. Verona (2008), F. Zerbini (2008) oraz artykuły w czasopismach, głównie „Journal of Marketing” oraz „European Journal of Marketing”; chodzi m.in. o takich autorów, jak: D.M. Gardner i in. (2000), G. Gliga i N. Evers (2010), G. John i in. (1999), S.L. Vargo i R.F. Lusch (2004). Na te publikacje autor będzie się powoływał.

Jak wspomniano, polska literatura jest w tym względzie bardzo uboga. Oprócz autora niniejszego artykułu piszą na ten temat głównie: L. Białoń (2010), A. Pomykalski (2001), I.P. Rutkowski (2011). Pierwszą w Polsce książkę w tym obszarze nt. Innowacje techniczne a działalność marketingowa opublikował A.H. Jasiński (1998). Stąd rozważania w tej pracy będą oparte przede wszystkim na literaturze zagranicznej.

$\mathrm{Z}$ przeglądu literatury światowej wynikają m.in. następujące wnioski: (a) w praktycznej działalności przedsiębiorstw innowacje i marketing często „chodzą” osobno; (b) porażki nowych, innowacyjnych produktów wynikają czasem $\mathrm{z}$ nieumiejętnego marketingu wprowadzającego je na rynek; (c) zdarza się, że marketingowcy niezbyt chętnie współpracują z menedżerami ds. innowacji, zaś (d) dla menedżerów innowacji ważniejsze jest często osiągnięcie naukowo-techniczne per se niż jego późniejszy sukces rynkowy. Stąd w przestudiowanej literaturze zagranicznej można znaleźć szereg postulatów, a m.in.:

- Marketing musi być bardziej innowacyjny, zaś innowacje muszą być mocniej powiązane z marketingiem (Kumar, 2004, s. 207-208).

- Wyższość technologiczna nie jest gwarancją sukcesu firmy. Prawdopodobieństwo sukcesu jest maksymalizowane dopiero poprzez kombinację wyższości technologii ze zdolnościami marketingowymi (Gliga, Evers, 2010).

- Marketing powinien zbudować mosty między innowacją a rynkiem (Sandberg, 2008, s. 2).

- Skuteczny marketing jest prawdopodobnie najbardziej krytycznym czynnikiem w udanej eksploatacji istniejących zasobów technologicznych firmy (Ford, Saren, 2001, s. 159). 
- Autorzy nawołują marketingowców do większego zainteresowania innowacjami, zarówno przyrostowymi, jak i radykalnymi. Po to, żeby wzrosła rola marketingu, większy nacisk musi być położony na rozwój zdolności działań marketingowych na rzecz innowacji (Jones, Tollin, 2008, s. 126 i 150).

- Marketing powinien być prowadzony wspólnie z klientami z jednej strony i z menedżerami innowacji z drugiej. Dzięki takiemu wspólnemu (collaborative) marketingowi można poprawić skuteczność zarówno marketingu, jak i - zwłaszcza - procesu innowacyjnego (Prandelli, Verona, 2008, s. 346).

Spośród wymienionych wyżej postulatów najważniejszy wydaje się ten ostatni, bowiem zaangażowanie klientów w działalność innowacyjną i marketingową uznaje się dziś powszechnie za podstawowy warunek sukcesu innowacji na rynku.

\section{Innowacja produktowa jako element marketingu-mix}

J ednym z elementów „klasycznej” mieszanki marketingowej (marketing-mix) jest „produkt”. Jest to pojęcie bardzo szerokie, choć umowne; obejmuje bowiem m.in. nowy produkt oraz usługę, markę, a także opakowanie $\mathrm{z}$ etykietą - zwykle w przypadku artykułów konsumpcyjnych. „Produkt” zazwyczaj rozpoczyna proces marketingowy rozumiany jako proces formułowania oferty marketingowej przedsiębiorstwa. Tak więc innowacja produktowa należy - z natury rzeczy - do jednego z elementów owej mieszanki. Innymi słowy, pierwszy punkt styczności procesu innowacyjnego - którego rezultatem jest innowacja - $\mathrm{z}$ marketingiem stanowi właśnie produkt. G. Gliga i N. Evers (2010) używają określenia „powierzchnia styku technologii i marketingu” (technology-marketing interface), mając na myśli zarówno technologie produktowe, jak i procesowe.

Nowsza koncepcja mieszanki marketingowej według R. Lauterborna (1990), czyli 4C (customer, cost, covenience, communication), nie ma tutaj zastosowania. $\mathrm{W}$ tej koncepcji produkt ma bowiem charakter niejako wtórny, występuje w tle każdego z czterech C.

Nowy produkt jest oczywiście tworzony po to, by go potem wprowadzić na rynek. Współcześnie ów rynek to często cyberprzestrzeń, czyli rynek elektroniczny/ wirtualny, który oczekuje produktu cyfrowego. Chodzi tu de facto o cyfrowy zapis nowego produktu. Jak pisze S. Łobejko z zespołem (2019, s. 60-61), jesteśmy świadkami procesu systematycznego nasycania produktów rozwiązaniami cyfrowymi aż do wykreowania całkowicie cyfrowego produktu. Cyfrowy zapis wyrobu może wspierać działania marketingowe, pozwalając na jego wizualizację w przestrzeni wirtualnej.

Jak zatem marketingowcy postrzegają innowacje? Nieco inaczej niż badacze, projektanci i technolodzy, którzy wysoko sobie cenią poziom zaawansowania naukowo-technicznego oraz skalę nowości danego rozwiązania. Interesująco odpowiadają na to pytanie autorzy podręcznika Strategic marketing: innowacja jest definiowana poprzez skalę zmian, jaką powoduje ona w zachowaniu konsumentów lub we „wzorcach konsumpcji” i w konsekwencji w strukturze rynku (Mooradian i in., 2012, s. 268). Dodajmy, że obok wymienionych niżej konsekwencji rynkowych z tytułu komercjalizacji innowacji dla marketingowców ważny jest również stopień trudności działań wprowadzających daną nowość na rynek.

Produkt jako element marketingu-mix jest traktowany - przynajmniej w teorii - jako narzędzie marketingowego oddziaływania na rynek. Nowy produkt może bowiem lepiej lub inaczej zaspokoić istniejące potrzeby społeczne albo wzbudzić, uzmysłowić potencjalnym nabywcom potrzebę jego posiadania czy użytkowania. Jego wprowadzenie na rynek (komercjalizacja) może wywołać następujące konsekwencje rynkowe (Wrzosek, 1994):

- tworzenie się nowych segmentów rynkowych,

- zanikanie niektórych z istniejących rynków - w rezultacie pojawienia się innych nowości,

- konieczność nowych form i sposobów ich oferowania/udostępniania - zmiany w kanałach dystrybucji,

- wypadanie konkurentów z rynku w wyniku nasilenia się procesów konkurowania,

- pojawienie się sytuacji monopolistycznej, którą tworzy producent-innowator,

- neutralizacja przewagi negocjacyjnej nabywców.

Dodajmy do tego jeszcze takie zjawiska, jak: pojawienie się nowej marki na rynku, zwiększenie barier wejścia dla firm konkurencyjnych czy wzrost przeciętnej ceny na danym rynku (nowości typu high-tech mogą ciągnąć ceny w górę). Tak więc zakres i zasięg zmian rynkowych, będących konsekwencjami komercjalizacji innowacji, mogą być bardzo szerokie.

Jak zatem widać, innowacja produktowa - zanim trafi na rynek - musi trafić w ręce specjalistów od marketingu, którzy powinni nadać jej odpowiednią (zwykle nową) markę, wyposażyć w opakowanie (jeśli dany produkt tego wymaga) i uzupełnić o ewentualne usługi towarzyszące (zwane zazwyczaj posprzedażnymi). Dopiero potem nowy produkt/markę można wprowadzić na rynek zgodnie z opracowaną wcześniej strategią komercjalizacji (Gwarda-Gruszczyńska, 2013; Trzmielak, 2013).

Podsumowując dotychczasowe rozważania: Innowacja produktowa pełni podwójną rolę: jest (1) celem i zarazem efektem procesu innowacyjnego oraz (2) instrumentem marketingowym.

W literaturze marketingowej rozważa się nowy produkt w kontekście cyklu rozwoju produktu (cykl RNP) (Kotler, 1999; Mohr i in., 2010; Rutkowski, 2007; 2011; Scheuing, 1998). Jednakże marketingu nie można ograniczać tylko do nowego wyrobu wprowadzanego na rynek przez istniejące przedsiębiorstwo. Przedmiotem działań marketingowych może być równie dobrze nowa technologia produkcyjna oferowana do sprzedaży czy udzielenia licencji. Co więcej, obiektem działalności marketingowej powinna być też nowa firma innowacyjna typu startup czy spin-off, wchodząca na rynek (spin-off firm to tzw. firma odpryskowa, natomiast przez startup 
rozumiemy małą, nową firmę oferującą innowacyjny produkt czy usługę opartą na nowej technologii). Takie przedsiębiorstwo staje przed podwójnym wyzwaniem - dwojakim wejściem na rynek: trzeba wprowadzić nań zarówno nową firmę, jak i nowy produkt materialny lub nową usługę.

Pojęcia "proces rozwoju nowego produktu” oraz "proces innowacyjny", rozważane w ekonomice i zarządzaniu innowacjami, zachodzą na siebie. To drugie jest pojęciem nieco innym, lecz także trochę szerszym, bowiem: (a) uwzględnia prace badawczo-rozwojowe $(B+R)$, (b) dotyczy również innowacji procesowych, (c) jego realizacja wykracza zazwyczaj poza przedsiębiorstwo oraz (d) rozwój nowego produktu jest często zdeterminowany przez aktualnie stosowaną w firmie technologię produkcji lub przez regulacje rynkowe, dotyczące np. sprzedaży, cen, reklamy określonych towarów (Jasiński i in., 2019, s. 33). Również klasyfikacje faz/etapów procesu RNP i procesu innowacyjnego są nieco odmienne, niemniej można powiedzieć, że punkt widzenia marketingowców i punkt widzenia innowatorów są bardzo zbliżone do siebie.

\section{Znaczenie marketingu dla innowacji technicznych}

$\mathbf{N}$ owy wyrób, będący rezultatem cyklu RNP, jest wprowadzany przez jego producenta na konkurencyjny rynek. Jak wyraził się twórca ekonomiki innowacji, Ch. Freeman (1985): „firma, która nie wprowadza innowacji - umiera", co nabrało szczególnego sensu w warunkach nasilającej się konkurencji globalnej. Przedsiębiorstwa muszą więc stale generować pomysły na nowe produkty i technologie produkcyjne, poszukując ich nie tylko wewnątrz, u siebie, ale przede wszystkim w swoim otoczeniu - wśród klientów, dostawców, instytucji naukowo-badawczych, czy też podpatrując konkurentów. Generowanie pomysłów to pierwsza faza - etap inicjowania procesu/projektu badawczego czy innowacyjnego. Działania, takie jak poszukiwanie pomysłów, ich gromadzenie, weryfikacja i selekcja, składające się na tę fazę, nie są jednak możliwe bez odpowiednich badań rynku.

Jak wiadomo, badania rynkowe wchodzą w skład badań marketingowych, bez których obecnie nie można sobie wyobrazić prowadzenia działań marketingowych. Wychodzimy więc z założenia, że współczesny, szeroko rozumiany marketing to badania (marketingowe) plus działania (marketingowe). Jeśli tak, to możemy stwierdzić, iż innowacja zazębia się z marketingiem już na samym początku procesu innowacyjnego. Jest to ich drugi punkt styczności. Dlatego nie można zgodzić się z tezą F. Krawca (2005, s. 173), że: „Dziś marketing umiejscowiony jest na końcu łańcucha produkcji”.

Zazwyczaj tuż przed komercjalizacją, jako ostatnią fazą procesu innowacji, mogą ponownie być potrzebne badania marketingowe (chodzi o testowanie produktu), a na pewno w jej trakcie, tj. podczas procesu akceptacji nowości na rynku. Jak potwierdzili empirycznie P. Bartkowiak i I.P. Rutkowski (2016), istnieje pozytywna korelacja między stopniem wykorzystania informacji pochodzącej z badań marketingowych a powodzeniem nowego produktu na rynku. Zauważmy jeszcze, że komercjalizacja innowacji produktowej stanowi jednocześnie pierwszą fazę rynkowego cyklu życia produktu (CŻP), kiedy podjęte działania wprowadzające zaczynają skutkować jego sprzedażą. Komercjalizacja stanowi zatem trzeci punkt styczności działalności innowacyjnej $\mathrm{z}$ marketingową.

Tak więc marketing ma do odegrania największą rolę w pierwszej i ostatniej fazie procesu innowacyjnego.

Powyższe rozważania potwierdzają wniosek płynący z postulatów wymienionych na początku tego artykułu, że marketing należy traktować jako imperatyw, którym musi kierować się przedsiębiorstwo w swojej działalności innowacyjnej. Dotyczy on zarówno dojrzałych firm, jak i nowych typu startup, działających w obszarze innowacyjności technologicznej.

Na potrzeby przedsiębiorców/przedsiębiorstw technologicznych N. Evers, J. Cunningham i T. Hoholm (2014) definiują marketing jako „ciągły proces proaktywnego tworzenia i wykorzystywania szans na rynku (lokalnym i międzynarodowym) dzięki oferowaniu - opartej na technologii - propozycji wartości dla docelowych klientów, poprzez strategiczne projektowanie, zarządzanie i wdrażanie docelowego programu marketingowego" (Evers i in., 2014, s. 184), czyli programu działań marketingowych dotyczących danej nowości technicznej. Jednym $\mathrm{z}$ największych wyzwań dla takich firm jest nadanie ważności ich propozycji wartości i uzasadnienie popytu na taką propozycję. Jak piszą ci autorzy, pojawia się zatem problem, a raczej proces tzw. rynkowego potwierdzenia (market validation process - MVP) (Evers i in., 2014, s. 186). Rynkowe potwierdzenie na rynkach wysokich technologii jest rozumiane jako dynamiczny i interaktywny proces integrowania technologii (stanowiącej rdzeń przedsięwzięcia) i możliwości produkcyjnych z jednej strony - z ukrytymi, lecz wyraźnymi potrzebami klientów z drugiej (Miles i in., 2010). Dwa kluczowe realizowane równolegle podprocesy MVP to: (a) analiza ekosystemu przedsiębiorstwa, czyli de facto jego otoczenia marketingowego, oraz (b) testowanie koncepcji nowego biznesu jako procesu wykorzystywanego do oszacowania potencjalnego popytu i oceny rynkowej atrakcyjności danego pomysłu lub koncepcji (Evers i in., 2014). Przez ów „nowy biznes” można rozumieć właśnie innowację techniczną.

Należy pamiętać, że nową technologię/metodę produkcji można potraktować także jako produkt rynkowy, czyli przeznaczony do sprzedaży lub licencjonowania. Wówczas marketing jest potrzebny również w odniesieniu do nowych technologii. Wynika to chociażby z dwustronnych zależności, które często występują między innowacjami produktowymi i procesowymi. Otóż, zdarza się, że zaprojektowanie i wytworzenie nowego wyrobu, istotnie różniącego się od dotychczasowego portfela produktów danej firmy, wymaga zastosowania zupełnie nowych technologii wytwarzania. Albo też dzięki zastosowaniu nowych technologii produkcyjnych nie tylko unowocześnione zostaną procesy wytwórcze 
w przedsiębiorstwie, ale możliwe stanie się zaprojektowanie i wdrożenie zupełnie nowego produktu. Zresztą coraz częściej zdarza się, iż pojawiające się nowe wyroby jednoczą w sobie innowacje produktowe i procesowe. Tak było np. w przypadku smartfonu iPhone.

$\mathrm{Z}$ naszego punktu widzenia te drugie (procesowe) dość istotnie różnią się od tych pierwszych (produktowych), a mianowicie:

- nowa technologia produkcji bardziej przypomina - swoim charakterem - nową usługę (innowację usługową). Notabene, w marketingu usługa jest traktowana również jako produkt, tyle że niematerialny,

- nowa technologia wytwarzania jest lub może być przedmiotem marketingu instytucjonalnego (przemysłowego), adresowanego głównie do przedsiębiorstw,

- przyjmuje się powszechnie, że innowacje procesowe są znaczniej mniej wrażliwe na uwarunkowania rynkowe niż nowe produkty.

Owe różnice powodują pewną specyfikę marketingu nowych technologii produkcji. Otóż, z uwagi m.in. na niematerialny charakter innowacji procesowej, jej marketing jest dużo trudniejszy od marketingu innowacji produktowej.

Problematykę powiązań między nowymi technologiami a marketingiem podejmują np. D. Ford i M. Saren (2001), którzy, traktując technologie produkcyjne jako zasób przedsiębiorstwa, nawołują do właściwej ich eksploatacji - zarówno wewnątrz firmy, co oczywiste, jak i na zewnątrz. Pisząc o eksploatacji zewnętrznej, mają na myśli sprzedaż technologii głównie poprzez jej licencjonowanie, a także franczyzowanie.

W oparciu o badania wśród 703 firm brytyjskich z siedmiu sektorów przemysłu, przywołani wyżej autorzy stwierdzają stanowczo, że wydziały/oddziały marketingowe zajmują się przede wszystkim marketingiem wyrobów czy usług produkowanych przez firmę, a nie marketingiem technologii. Marketingowcy koncentrują się zwykle na "marketingu strony popytowej” - zgodnie z zasadą, że marketing zaczyna i kończy się na rynku, czyli na zewnątrz przedsiębiorstwa. W odniesieniu do eksploatacji technologii potrzebny jest „marketing strony podażowej”, bazujący na możliwościach technicznych firmy - w celu ich lepszego wykorzystania (Ford, Saren, 2001, s. 159). Opowiadają się oni, rzecz jasna, za integracją obu stron marketingu. I ten postulat należy w pełni poprzeć. Ich zdaniem, marketing nowych technologii ma charakter relacyjny (stąd termin: marketing relacji) (Ford, Saren, s. 162). W literaturze polskiej wstępną koncepcję marketingu innowacji technicznych sformułował autor niniejszej publikacji (Jasiński, 1998, s. 92-106).

\section{Innowacje radykalne a innowacje przyrostowe}

$\mathbf{S}$ prawdźmy teraz, czy powiązania między działalnością innowacyjną a marketingową zależą od typu/ rodzaju innowacji. W literaturze można znaleźć liczne klasyfikacje innowacji w zależności od różnych kryteriów. Z naszego punktu widzenia niezwykle ważne jest kryterium rozległości/skali zmiany reguł gry, spowodowanych przez dane rozwiązanie techniczne. Otóż, biorąc po uwagę to kryterium, powszechnie rozróżnia się: (1) innowacje przełomowe/radykalne, np. telefon komórkowy, drukarka 3D, laptop, obróbka cieplna zamiast obróbki skrawaniem w hutnictwie oraz (2) innowacje przyrostowe albo inaczej inkrementalne. W skali świata dominują liczebnie te drugie. Niektórzy rozróżniają jeszcze innowacje transformacyjne, które przekształcają istniejące lub wręcz stwarzają nowe sektory gospodarki, np. telefon, maszyna do pisania, komputer, samochód (Utterback, 1994, s. 256). Z kolei Ch. Christensen wprowadził pojęcie innowacji zakłócającej, przerywającej tok rozwoju branży (2010, s. 18), ale można ją potraktować jako odmianę innowacji przełomowej.

Innowacje radykalne zazwyczaj wymagają lub wywołują zmianę modelu biznesowego przedsiębiorstwa, towarzyszy im bardzo duże ryzyko, ale jednocześnie - ze względu na swoją rewolucyjność - takie zmiany mogą być znacznie dochodowe. Jednak nie każde przedsiębiorstwo stać na taką strategię. W przypadku innowacji przyrostowych zaś zmiana ma charakter ewolucyjny, towarzyszy jej mniejsze ryzyko i jednocześnie jest w stanie wpasować się w procedury obecne w organizacji (Szopik-Depczyńska, 2018, s. 20). Dodajmy, że spodziewać się można wówczas nie aż tak wysokiej dochodowości z tytułu takiej innowacji.

N. Evers, J. Cunningham i T. Hoholm (2014, s. 195) różnicują narzędzia/techniki testowania „nowego biznesu”, w ramach wspomnianego procesu rynkowego potwierdzania, w zależności od typu innowacji. Mianowicie, nieco upraszczając zagadnienie, piszą, że:

1) innowacje przyrostowe, mające charakter raczej ewolucyjny, oparte są na znanym modelu innowacji ciągnionej przez rynek. W takim przypadku zastosowanie analizy statystycznej conjoint pozwoli zrozumieć, jak ludzie dokonują wyboru między produktami czy usługami, jak porównują atrakcyjność różnych ofert;

2) innowacje radykalne, mające raczej charakter rewolucyjny, bazują na modelu innowacji pchanej przez technikę. W tym przypadku autorzy ci zalecają testowanie Beta-site, czyli testowanie prototypu wśród specjalnie dobranych użytkowników (zwykle firm) jako potencjalnych klientów. Przydatny może okazać się tutaj model innowacji kierowanej przez użytkownika (user-driven innovation - UDI).

Jak stwierdza N. Kumar (2004), w odniesieniu do innowacji przyrostowych rola marketingu jest jasna: poznać reakcje, odczucia, wrażenia klientów oraz zarządzać procesem wprowadzania nowości na rynek. Natomiast w stosunku do innowacji przełomowych rola marketingu jest inna, bardziej ograniczona i często przeciwstawna do głęboko zakorzenionych przekonań marketingowych. Wyzwaniem jest tutaj znalezienie segmentu rynkowego, dla którego propozycja radykalnej wartości jest atrakcyjna. 
D. Ford i M. Saren (2001, s. 162) uważają, że im bardziej innowacyjny produkt, tym większe prawdopodobieństwo, iż potencjalni nabywcy początkowo nie będą w stanie zauważyć jego wszystkich korzyści. Nabywcy często nie umieją wyartykułować swoich potrzeb lub wyobrazić sobie możliwych sposobów wykorzystania nowej techniki. Na przykład założyciele Sony początkowo nie uwierzyli w badanie, które wykazało, że konsumenci nie kupią magnetofonu, który nie nagrywa.

Również J. Mohr z zespołem (2010) pisze, iż działania marketingowe powinny być zróżnicowane w stosunku do innowacji radykalnych i przyrostowych. (Notabene, autorka chwilami utożsamia nowości radykalne $\mathrm{z}$ innowacjami w zakresie wysokiej techniki). Jej zdaniem, to różnicowanie wynika $\mathrm{z}$ cech charakterystycznych innowacji przełomowych, w których przypadku: ryzyko niepowodzenia na rynku jest duże; występuje słaba konkurencja bezpośrednia, przynajmniej na początku; dotychczasowa segmentacja rynku może być nieprzydatna; potencjalni nabywcy nie są jeszcze dobrze znani. Dlatego marketing nacelowany na wczesnych nabywców (tzw. pionierów) różni się od marketingu adresowanego do późnych, zwykle tradycjonalistycznych odbiorców. Standardowe praktyki marketingowe zawodzą w odniesieniu do innowacji radykalnej. Promocja takiego nowego produktu staje się de facto promocją nowej marki, na pewno nie dla tradycjonalistycznych klientów (Mohr i in., 2010).

Kwestię zróżnicowanego podejścia w zależności od poziomu nowości danego rozwiązania technicznego podejmują G. Gliga i N. Evers (2010) w odniesieniu do małych i średnich przedsiębiorstw (MŚP) opartych na wysokiej technice. Na podstawie badań wśród MŚP w sektorach high-tech w Unii Europejskiej piszą oni, iż innowacje przyrostowe i przełomowe wymagają zazwyczaj innych strategii marketingowych. I odwrotnie: ukierunkowanie badań naukowych na innowację inkrementalną czy radykalną zależy często od przyjętej strategii marketingowej przedsiębiorstwa.

Wreszcie B. Sandberg (2008), który całą swoją książkę poświęcił zarządzaniu i marketingowi radykalnych innowacji, stwierdza, że skoro przełomowym innowacjom towarzyszy olbrzymia niepewność rynkowa, wymaga się bacznej obserwacji klientów i ich potrzeb podczas całego procesu innowacyjnego. Dlatego marketing należy postrzegać jako działalność wspierającą, a nie jako osobną funkcję. Zasadnicza trudność, jaka się tu pojawia, polega na tym, że firma może nawet nie wiedzieć, kim będą nabywcy takiej (radykalnej) innowacji. A nawet jeśli klienci są znani, często nie są w stanie wyartykułować swej potrzeby na kompletnie nowy, nieznany dotąd produkt czy usługę. „W przypadku rozwijania innowacji przełomowych, produkty, rynki i granice konkurencji są $\mathrm{w}$ tym czasie $\mathrm{w}$ stanie nieustannych zmian ( $\mathrm{z}$ ang. flux)" (Sandberg, 2008, s. 3).

Jak widzimy, przed marketingiem nowego produktu pojawiają się dodatkowe, poważne wyzwania, jeśli dotyczy on innowacji radykalnej. Tak więc decyzja zarządu przedsiębiorstwa, że „musimy stworzyć przełomową innowację", nie należy do łatwych.

\section{Proces innowacyjny a orientacja marketingowa}

$\mathbf{Z}$ dotychczasowych rozważań można odnieść wrażenie, że mówimy tutaj o przedsiębiorstwie o orientacji marketingowej (OM), czyli zorientowanym na rynek. Na proces innowacyjny trzeba bowiem patrzeć przez pryzmat OM. Obecnie jednak dość popularna jest teza mówiąca, że kurczowe trzymanie się dosłownie rozumianej orientacji marketingowej prowadzi często do powstania reaktywnej, przyrostowej innowacji produktowej i może nawet utrudniać pojawienie się innowacji radykalnej (Jones, Tollin, 2008). Autorzy ci z pewnością mają tu na myśli tzw. rynkową reaktywność jako jedną z dwóch odmian OM obok proaktywności.

B. Sandberg (2008) utożsamia OM z orientacją na klienta, chociaż występują jeszcze dwa inne rodzaje OM, a mianowicie orientacja na konkurentów i orientacja na dostawców. Autor definiuje wspomniane wyżej odmiany (reaktywność i proaktywność) następująco:

- reaktywność rynkowa „polega na reagowaniu na pewne okoliczności na rynku po tym, jak zaczynają one mieć bezpośredni wpływ na firmę” (s. 29),

- proaktywność rynkowa natomiast polega „albo na działaniu opartym na informacjach gromadzonych o rynku, zanim pewne okoliczności zaistniałe na nim zaczną mieć bezpośredni wpływ na firmę, albo na celowym wpływaniu i kreowaniu zmian na rynku" (s. 33).

Zdaniem tegoż autora, zachowanie proaktywne staje się obecnie wymogiem, wręcz imperatywem. Dopowiedzmy jeszcze, że to właśnie firma powinna być prekursorem (kreatorem) zmian na rynku (Jasiński, 1998). Oczywiście, zakres/skala proaktywności zorientowanej na klienta ulega zmianom podczas procesu innowacji (radykalnej): proaktywność ta jest zwykle bardzo wysoka w fazie generowania pomysłów; w kolejnych fazach jej zakres zmniejsza się, przy czym najmniejszy jest na etapie prototypu; wreszcie, w fazie komercjalizacji proaktywność jest ponownie wysoka. Czasami należy wprowadzić oczekiwane przez klientów modyfikacje już po wejściu innowacji na rynek (Sandberg, 2008). Zgadzając się z tym autorem, zauważyć jednak trzeba, że przestawienie się z orientacji reaktywnej na proaktywną nie jest tak proste, jakby wynikało z jego rozważań.

W obu odmianach orientacji marketingowej, a zwłaszcza w przypadku proaktywności rynkowej, podstawą działania jest kreatywność. Spośród różnych jej definicji najbardziej odpowiednia wydaje się tutaj definicja M. Brzezińskiego (2009, s. 15), zgodnie z którą kreatywność to „Zdolność człowieka do twórczego wykorzystania potencjału umysłowego przy tworzeniu nowych, oryginalnych pomysłów w formie koncepcji, produktów itp. z wykorzystaniem wiedzy, doświadczenia oraz olśnienia twórczego, czerpanego $\mathrm{z}$ niewyczerpywalnych pokładów kreatywnej wyobraźni”. Może mieć ona charakter indywidualny i zbiorowy. Dodajmy, że kreatywność jest niezbędna zarówno w działalności marketingowej, jak i innowacyjnej. 
Autor pracy Creativity, Cognition and the Market nawołuje do kreatywności w celu tworzenia nowej wartości dla klienta (Christensen, 2008). Nawiązując do wcześniejszych prac M. Rhodesa, pisze on, iż na kreatywność składa się 4xP (inne niż u E.J. McCarthy’ego, 1965), a mianowicie:

- kreatywna persona/osoba - może to być wynalazca lub menedżer innowacji,

- proces kreatywnego myślenia - taki charakter powinien mieć cały proces innowacyjny,

- kreatywny produkt - powinien on posiadać trzy cechy: nowość (oryginalność), przydatność (zdolność do rozwiązania problemu klienta) i synteza (finalna kompletność),

- kreatywna prasa. Autor ma tutaj na myśli takie czynniki środowiskowe, jak kontekst organizacyjny czy klimat sprzyjający innowacjom. Pod wpływem pracy R. Floridy (2004) to czwarte P zastąiono słowem „miejsce” (place), np. miasto. Chodzi generalnie o tzw. środowisko innowacyjne, które powinno mieć „dobrą prasę”. W ujęciu przestrzennym, środowisko innowacyjne jest to zintegrowany terytorialnie zbiór podmiotów (organizacja terytorialna), skąd bierze swój początek proces innowacji (Maillat, 2002).

Z powyższego nasuwają się przynajmniej dwa wnioski:

1. Koncepcja ta dobrze tłumaczy, na czym ma polegać kreatywność w odniesieniu do procesu innowacyjnego.

2. Za tworzenie wartości odpowiada i działalność innowacyjna, i marketingowa. Chodzi tu o wartość zarówno dla klienta, jak i dla przedsiębiorstwa (o czym będzie mowa w kolejnym artykule).

\section{Podsumowanie}

$\mathbf{R}$ easumując, główna hipoteza badawcza została zweryfikowana pozytywnie, bowiem istnieją przynajmniej trzy "punkty styczności”, gdzie działalność innowacyjna zazębia się z działalnością marketingową, a mianowicie:

1) innowacja produktowa, będąca rezultatem procesu innowacji, wchodzi w skład jednego z P (Produktu) w mieszance marketingowej,

2) generowanie pomysłów na nowy produkt, jako pierwsza faza procesu innowacyjnego, wymaga przeprowadzenia odpowiednich badań marketingowych,

3) komercjalizacja innowacji, jako ostatni etap procesu innowacyjnego, stanowi jednocześnie pierwszą fazę cyklu życia (nowego) produktu, który to cykl jest przedmiotem zarządzania marketingowego.

Okazuje się więc, że innowacja produktowa, która znajduje się na wyjściu z tego procesu, jest jednocześnie wykorzystywana jako narzędzie marketingowego oddziaływania na rynek. W przypadku innowacji radykalnej działania marketingowe są dużo bardziej skomplikowane i trudniejsze niż w przypadku innowacji przyrostowej. W odniesieniu do innowacji przełomowej zalecana jest jedna $\mathrm{z}$ dwóch odmian orientacji marketingowej przedsiębiorstwa, określana jako proaktywność rynkowa. Ponadto więcej uwagi należy poświęcić marketingowi nowych technologii produkcyjnych, który ma swoją specyfikę.

We współczesnym przedsiębiorstwie działalność innowacyjna zazębia się z marketingową w tylu miejscach, że nie mogą one funkcjonować obok siebie, lecz wspólnie. Ten postulat nie jest łatwy do zrealizowania w praktyce, bowiem menedżerowie ds. innowacji i ds. marketingu zwykle działają w ramach odrębnych pionów/działów przedsiębiorstwa. Można im podpowiedzieć następujące sposoby współpracy: regularne spotkania zespołów z obu pionów, wymienianie się swoimi planami strategicznymi i bieżącymi planami pracy, wspólne spotkania z potencjalnymi klientami/użytkownikami nowego produktu, naprzemienne występowanie pracowników obu pionów w roli przyszłych klientów. Oczywiście, ktoś w zarządzie przedsiębiorstwa powinien nadzorować ową współpracę.

\section{prof. dr hab. Andrzej H. Jasiński \\ Uniwersytet Warszawski \\ Wydział Zarządzania \\ ORCID: 0000-0001-7433-8803 \\ e-mail: ahj@onet.pl}

\section{Przypis}

1) Niniejszy artykuł jest jednym $\mathrm{z}$ dwóch, które powstały na bazie projektu badawczego: Gdzie innowacja spotyka się z marketingiem?, który został zrealizowany przez autora w ramach badań własnych na Wydziale Zarządzania Uniwersytetu Warszawskiego. Drugi artykuł będzie nosić tytuł: Wartość jako łacznik między innowacją a marketingiem. W obu artykułach dominują aspekty teoretyczne; projekt nie przewidywał badań empirycznych. Autor miał dostęp do cytowanej literatury zagranicznej podczas pobytu w Szkole Biznesu Uniwersytetu Northumbria w Newcastle, W. Brytania.

\section{Bibliografia}

[1] Bartkowiak P., Rutkowski I.P. (2016), Informacja w kształtowaniu procesu innowacji produktu, „Przegląd Organizacji”, Nr 3, s. 34-42.

[2] Białoń L. (2010), Marketingowe wsparcie procesów innowacyjnych, [w:] L. Białoń (red), Zarządzanie działalnościa innowacyjna, Placet, Warszawa, s. 321-368.

[3] Brzeziński M. (2009), Organizacja kreatywna, Wydawnictwo Naukowe PWN, Warszawa.

[4] Christensen B.T. (2008), Creativity, Cognition and the Market, [in:] Tollin K., Caru A., (eds.), Strategic Market Creation, John Wiley \& Sons, Chichester, pp. 48-70.

[5] Christensen C.M. (2010), Przełomowe innowacje, Wydawnictwo Naukowe PWN, Warszawa.

[6] Drucker P. (1973), Management, Harper \& Row, New York.

[7] Doyle P. (1998), Introduction, [in:] P. Doyle, S. Bridgewater (eds.), Innovation in Marketing, Butterworth-Heinemann, Oxford, pp. IX-XII. 
[8] Evers N., Canningham J., Hoholm T. (2014), Technology Entrepreneurship: Bringing Innovation to the Marketplace, Pelgrave, Basingstoke.

[9] Florida R. (2004), The Rise of the Creative Class, Basic Books, New York.

[10] Ford D., Saren M. (2001), Managing and Marketing Technology, Thompson Learning, London.

[11] Freeman Ch. (1985), The Economics of Industrial Innovation, F. Pinter, London.

[12] Gardner D.M., Johnson F., Lee M., Wilkinson I. (2000), A contingency Approach to Marketing High-technology Products, „European Journal of Marketing”, Vol. 34, No. 9/10, pp. 1053-1077.

[13] Gliga G., Evers N. (2010), Marketing Challenges for High-technology SMEs, „Innovative Marketing”, Vol. 6, No. 3, pp. 103-112.

[14] Gwarda-Gruszczyńska E. (2013), Modele procesu komercjalizacji nowych technologii $w$ przedsiębiorstwach, Wydawnictwo Uniwersytetu Łódzkiego, Łódź.

[15] Jasiński A.H. (1998), Innowacje techniczne a działalność marketingowa, WSPiZ, Warszawa.

[16] Jasiński A.H., Głodek P., Jurczyk-Bunkowska M. (2019), Organizacja $i$ zarzadzanie procesami innowacyjnymi, PWE, Warszawa.

[17] John G., Weiss A.M., Dutta S. (1999), Marketing in Technology-intensive Markets, „Journal of Marketing”, Vol. 63, No. 4(sup.1), pp. 78-91.

[18] Jones R., Tollin K. (2008), Marketing's Role for Firms' Renewal and Innovation Capacity, [in:] K. Tollin, A. Caru (eds.), Strategic Market Creation, John Wiley \& Sons, Chichester, pp. 124-157.

[19] Kotler Ph. (1999), Kotler o marketingu, PSB, Kraków.

[20] Krawiec F. (2005), Marketing w firmie przyszłości, Difin, Warszawa.

[21] Kumar N. (2004), Marketing as Strategy, Harvard Business School Press, Boston.

[22] Lauterborn R. (1990), New Marketing Litany: Four P's Passe: C-Words Take Over, „Advertising Age”, Vol. 61, No. 41, pp. 26.

[23] Łobejko S., Plinta D., Sosnowska A. (2019), Strategie i modelowanie rozwoju produktów innowacyjnych, PWE, Warszawa.

[24] Maillat D. (2002), Globalizacja, terytorialne systemy produkcyjne i środowiska innowacyjne, Rector's Lecture, Wydawnictwo AE w Krakowie, Kraków.

[25] Matusiak K.B. (2010), Budowa powiązań nauki z biznesem w gospodarce opartej na wiedzy, Oficyna Wydawnicza SGH, Warszawa.

[26] McCarthy E.J. (1965), Basic Marketing, Irwin, New York.

[27] Miles M.P., Little V., Brookes R., Morrish S.C. (2010), Market Validation in the Context of New High-tech Ventures, https://docplayer.net/14498361-Market-validation-in-the-context-of-new-high-tech-ventures.html, access date: 6.05.2020.

[28] Millier P. (1999), Marketing the Unknown: Developing Market Strategies for Technical Innovations, John Wiley \& Sons, Chichester.

[29] Mohr J. (2001), Marketing of High-tech Products and Innovations, Prentice-Hall, New Jersey.
[30] Mohr J. i in. (2010), Marketing of High-tech Products and Innovations, Prentice-Hall, New Jersey.

[31] Mooradian T.A. i in. (2012), Strategic Marketing, Pearson Education, New Jersey.

[32] OECD (2008), Podręcznik Oslo. Zasady gromadzenia i Interpretacji danych dotyczacych innowacji, Trzecia edycja, OECD/Eurostat, Warszawa.

[33] Pomykalski A. (2001), Zarządzanie innowacjami, Wydawnictwo Naukowe PWN, Warszawa-Łódź.

[34] Prandelli E., Verona G. (2008), Co-developing New Products with Customers, [in:] K. Tollin, A. Caru (eds.), Strategic Market Creation, John Wiley \& Sons, Chichester, pp. 362-388.

[35] Rutkowski I.P. (2007), Rozwój nowego produktu, PWE, Warszawa.

[36] Rutkowski I.P. (2011), Strategie produktu, PWE, Warszawa.

[37] Sandberg B. (2008), Managing and Marketing Radical Innovations, Routledge, London.

[38] Scheuing E.E. (1998), New Product Management, Merrill Publishing Company, Columbus.

[39] Szopik-Depczyńska K. (2018), Koncepcja innowacji kreowanej przez użytkownika $w$ działalności badawczo-rozwojowej przedsiębiorstw, Wydawnictwo Uniwersytetu Szczecińskiego, Szczecin.

[40] Tollin K., Caru A. (eds.), (2008), Strategic Market Creation, John Wiley \& Sons, Chichester.

[41] Trzmielak D. (2013), Komercjalizacja wiedzy i technologii - determinanty i strategie, Wydawnictwo Uniwersytetu Łódzkiego, Łódź.

[42] Utterback J. (1994), Mastering the Dynamics of Innovation, Harvard Business School Press, Boston.

[43] Vargo S.L., Lusch R.F. (2004), Evolving to a New Dominant Logic for Marketing, „Journal of Marketing”, Vol. 68, No. 1, pp. 1-17.

[44] Wrzosek W. (1994), Funkcjonowanie rynku, PWE, Warszawa.

[45] Zerbini F. (2008), Supplying Value to Customers through Innovation in B2B Services, [in:] K. Tollin, A. Caru (eds.), Strategic Market Creation, John Wiley \& Sons, Chichester, pp. 229-256.

\section{Where Innovation Meets Marketing. Theoretical Aspects}

\section{Summary}

Innovation activities of the contemporary enterprise overlap with its marketing activities. If so, we have formulated a hypothesis that surely there exist some 'interfaces' between the two spheres of firms' activities. So, the article's main aim is an attempt to answer the following question: Where do those overlaps take place? In other words, we have tried to identify those 'interfaces'. As turned out, there exist at least three such points of contact between innovation and marketing.

\section{Keywords}

innovation, innovation process, marketing 